This item is the archived peer-reviewed author-version of:

The Assisi Think Tank Meeting Survey of post-mastectomy radiation therapy in ductal carcinoma in situ : suggestions for routine practice

\title{
Reference:
}

Montero-Luis A., Aristei C., Meattini I., Arenas M., Boersma L., Bourgier C., Coles C., Cutuli B., Falcinelli L., Kaidar-Person O., ....- The Assisi Think Tank Meeting Survey of post-mastectomy radiation therapy in ductal carcinoma in situ : suggestions for routine practice

Critical reviews in oncology, hematology / Chemical Rubber Company [Cleveland, Ohio] - ISSN 1879-0461 - New york, Elsevier science inc, 138(2019), p. 207213

Full text (Publisher's DOI): https://doi.org/10.1016/J.CRITREVONC.2019.04.016 


\section{The Assisi Think Tank Meeting Survey of post-mastectomy radiation therapy in ductal carcinoma in situ: Suggestions for routine practice}

Montero-Luis A1*; Aristei C2; Meattini I3; Arenas M4; Boersma L5; Bourgier C6; Coles C7; Cutuli B8; Falcinelli L9; Kaidar-Person O10; Leonardi MC11; Offersen B12; Marazzi F13; Rivera S14; Tagliaferri L15; Tombolini V16; Vidali C17; Valentini V18; Poortmans P19.

1) Radiation Oncology, University Hospital HM Sanchinarro, Madrid, Spain

2) Radiation Oncology, University of Perugia and Perugia General Hospital, Perugia, Italy

3) Radiation Oncology, Azienda Ospedaliero-Universitaria Careggi (AOUC), Florence, Italy

4) Radiation Oncology, University Hospital Sant Joan, Reus, Spain

5) Radiation Oncology, The Netherlands Cancer Institute, Antoni van Leeuwenhøek Huis, Amsterdam, Netherlands

6) Radiation Oncology, ICM-Val d'Aurelle, Univ Montpellier, Montpellier, France.

7) Radiation Oncology, Cambridge University Hospitals NHS Foundation Trust, Cambridge, UK.

8) Radiation Oncology, Institut du Cancer Courlancy, Reims, France.

9) Radiation Oncology, Perugia General Hospital, Italy.

10) Radiation Oncology, University of North Carolina, Chapel Hill, North Carolina, USA

11) Radiation Oncology, IEO, European Institute of Oncology IRCCS, Milan, Italy

12) Radiation Oncology, Aarhus University Hospital , Aarhus , Denmark.

13) Radiation Oncology, Fondazione Policlinico Universitario Agostino Gemelli IRCCS, Rome, Italy.

14) Radiation Oncology, Institut Gustave Roussy, Villejuif , France

15) Radiation Oncology, Fondazione Policlinico Universitario Agostino Gemelli IRCCS, Roma, Italy.

16) Radiation Oncology, Policlinico Umberto I, Sapienza University of Rome, Rome, Italy.

17) Radiation Oncology, Azienda Sanitaria Universitaria Integrata di Trieste (ASUITS), Trieste, Italy.

18) Radiation Oncology, Fondazione Policlinico Universitario Agostino Gemelli IRCCS, Roma, Italy.

19) Radiation Oncology, Institut Curie, Paris, France.

*Corresponding author: A. Montero; Radiation Oncology, University Hospital HM Sanchinarro, c/Oña 10, 28050 Madrid, Spain. E-mail: angel.monteroluis@gmail.com 


\begin{abstract}
Background: Risk factors for local recurrence after mastectomy in ductal carcinoma in situ (DCIS) emerged as a grey area during the second "Assisi Think Tank Meeting" (ATTM) on Breast Cancer.

Aim: To review practice patterns of post-mastectomy radiation therapy (PMRT) in DCIS, identify risk factors for recurrence and select suitable candidates for PMRT.

Methods: A questionnaire concerning DCIS management, focusing on PMRT, was distributed online via SurveyMonkey. .

Results: 142 responses were received from 15 countries. The majority worked in academic institutions, had 5-20 years work-experience and irradiated $<5$ DCIS patients/year. PMRT was more given if: surgical margins $<1 \mathrm{~mm}$, high-grade, multicentricity, young age, tumour size $>5 \mathrm{~cm}$, skin- or nipple- sparing mastectomy. Moderate hypofractionation was the most common schedule, except after immediate breast reconstruction ( $57 \%$ conventional fractionation).

Conclusions: The present survey highlighted risk factors for PMRT administration, which should be further evaluated.
\end{abstract}

Keywords: Breast cancer, Ductal carcinoma in situ, Post-mastectomy radiotherapy, Hypofractionation, Survey 


\section{Introduction}

Until the introduction of breast cancer population screening programs, diagnosis of ductal carcinoma in situ (DCIS) was infrequent, being found in less than 5\% of all new cancer diagnoses. At present, DCIS accounts for $20-25 \%$ of all new cases [1].

After breast conservative surgery (BCS) for DCIS, whole breast radiation therapy (WBRT) demonstrated its efficacy and safety by significantly reducing both in situ and infiltrating local relapses. Four large randomized studies with more than 12 years' median follow-up as well as meta-analyses of these studies, including one by the Early Breast Cancer Trial Collaborative Group, confirmed the benefit of WBRT in all patients, independently of age, size, grade, surgical margin status or presence of comedonecrosis [2-9]. WBRT may however, be omitted for women with very low risk tumours who, after discussing the pros and cons with their physicians, accept a small but significant increased ipsilateral relapse rate.

Since DCIS is considered a precursor of a potentially infiltrating malignancy, total mastectomy should constitute sufficient treatment and in fact, local recurrence rates are generally low. Mastectomy rates for DCIS have been rising again over the last few years and it has become the selected surgical option for almost $30 \%$ patients $[10,11]$ particularly for women in the youngest age-group and those with high-risk factors for relapse after BCS and WBRT e.g. multicentricity, large and/or high grade tumours, involved resection margins.

PMRT in pure DCIS is not routinely recommended as its role has not yet been well defined. For patients harbouring "high risk" factors several recent studies evaluated postmastectomy RT (PMRT) [12-19]. Consequently, identifying risk factors for recurrence after mastectomy is currently one of the main challenges in optimal DCIS management. Other controversial issues are whether to prescribe adjuvant endocrine therapy, and which drugs to use (tamoxifen or aromatase inhibitors).

One of the topics during the second "Assisi Think Tank Meeting" (ATTM) on Breast Cancer [20](1 ${ }^{\text {st }}-3$ rd March 2018), which was endorsed by the European Society for Radiotherapy \& Oncology (ESTRO), was the therapeutic approach in DCIS. A grey area that emerged during the discussion was the need to identify risk factors for local recurrence after mastectomy so as to select suitable candidates for PMRT. A questionnaire was designed to review the practice patterns of PMRT in the setting of pure DCIS and consensus was reached on key clinical questions that needed investigation in future 
clinical trials. The results of the survey and key points for the ATTM discussion of PMRT in DCIS are presented below.

\section{Material and methods}

The DCIS group at the ATTM designed a questionnaire based on current scientific literature, which was reviewed by the Expert Board Members (radiation and clinical oncologists who were experts in breast cancer) and subsequently revised in accordance with their comments. The questions raised in the questionnaire arose from the discussion held at the ATTM group meeting in March 2018. After an in-depth review of DCIS topic, its treatment options and the role of modern radiotherapy in its management, the greatest discrepancies were observed respecting to the role of PMRT after DCIS. As a result, the possibility was raised of gathering the opinion of a greater number of experts in breast cancer radiotherapy to obtain a real image of the role of PMRT in the context of the multidisciplinary treatment of DCIS. Questions raised are intended to explore existing gray areas regarding DCIS post-mastectomy radiation: when, how and why. Between June and July 2018, the questionnaire was distributed online to each ATTM participant via the online survey cloud-based software "SurveyMonkey" (SurveyMOnkey Europe, UC, Dublin, Ireland). Each participant was requested to answer the questionnaire and forward it, directly or via scientific societies, to colleagues who were active in the field of breast cancer. We suggested that per department only one reply was given, by the reference person for breast cancer. Items in the questionnaire referred to diverse aspects of DCIS management but focused on PMRT indications. The first 3 questions (Q1, Q2, Q3), addressed general topics such as country, institution type and years of experience in RT for breast cancer. Five questions referred to institutional experience with PMRT in DCIS and related risk factors (Q4, Q5, Q6, Q7, Q8). Three questions inquired about the influence of the different types of mastectomy and reconstruction on indications to PMRT (Q9, Q10, Q11) and seven (Q12, Q13, Q14, Q15, Q16, Q17, Q18) focused on technical aspects of RT. Three more questions (Q19, Q20, Q21) investigated bio-pathological DCIS characterization and addressed the issue of endocrine treatment. The last two questions (Q22, Q23) asked whether respondents were willing to participate in both retrospective and prospective studies, should the opportunity arise in the future. 
Survey participation was voluntary with no financial incentives. Ethical Approval was non-required.

Data are presented by descriptive statistics.

\section{Results}

A total of 142 participants from 15 countries answered the 23 survey questions (Q1) (Fig 1). The majority of responders (76.8\%) were from academic institutions while $19.7 \%$ worked in General Hospitals (Q2). The expertise of responding radiation/clinical oncologists (from now on referred to as radiation oncologists) ranged from under 5 years for $4.9 \%$ to over 20 years for $50 \%(\mathrm{Q} 3)$ (Table 1). Mastectomy for DCIS was limited to under 50 patients/year in most institutions but $>100$ patients/year received it in nearly $8 \%$ (Q4). The main factors for PMRT were close $(<1 \mathrm{~mm})$ surgical margins $(80.6 \%)$, high grade $(37.5 \%)$ and multicentricity $(28.5 \%)$. The strength of the indication increased with additional risk factors, including young age and tumour size $>5 \mathrm{~cm}(\mathrm{Q} 7, \mathrm{Q} 8)$ (Table 2). With or without immediate breast reconstruction (IBR), PMRT was rarely or never indicated by $90 \%$ of respondents and $85.9 \%$ declared they delivered it to under 5 patients a year (Q5, Q6). Whether IBR was autologous or heterologous (Q9, Q10) did not change the recommendation for PMRT for more than half of responders. To note $16.9 \%$ of radiation oncologists considered skin-sparing or nipple-sparing mastectomy as a major factor for prescribing PMRT (Q11) (Table3).

In cases of PMRT, 50\% of radiation oncologists recommended a radiation boost on the surgical scar only when margins were close or positive, whether with IBR or not (Q12). Complex advanced RT techniques (intensity modulated RT, volumetric arc therapy, tomotherapy) were not preferred by $65 \%$ of radiation oncologists and were reserved, for the most part, for situations that could not be adequately treated with conventional techniques, including field-in-field "forward-planned IMRT" (Q13). Nearly two-thirds (64\%) of radiation oncologists recommended using a bolus on the chest wall during treatment (Q14) (Table 4).

Moderate hypofractionation (2.5-3 Gy per fraction) and a conventional scheme (2 Gy per fraction) were used for PMRT (44.36\% and 40.84\%, respectively). In the presence of IBR, more than half of radiation oncologists $(57 \%)$ chose a conventional scheme. Likewise, 
when a boost was needed, most responders favoured a conventional scheme of 2 Gy/day for the whole treatment, independently of IBR (Q15, Q16, Q17, Q18) (Table 4). Immunohistochemistry was routinely performed in most institutions for quantitative determination of oestrogen receptor $(78.9 \%)$, progesterone receptor $(71.1 \%)$ as well as $\mathrm{Ki}-67$ (54.9\%) (Q19). In the presence of positive oestrogen receptors endocrine treatment was prescribed depending upon age, grade, margins or tumour size, by $69.6 \%$ of radiation oncologists, $47 \%$ of whom recommended tamoxifen (Q20, Q21) (Table 5).

Finally, survey responders were asked whether they were willing to participate in retrospective or prospective, observational or randomized trials on the use of PMRT in DCIS. More than $86 \%$ agreed to do so (Q22, Q23) (Table 6).

\section{Discussion}

The present survey investigated how radiation oncologists from different countries manage PMRT in DCIS. Although mastectomy is used in about $30 \%$ of patients, PMRT is rarely administered because local recurrence rates range from $0 \%$ to $7.5 \%$ [21], and 15 year breast-cancer related mortality rates from $1.74 \%$ to $2.26 \%$. The latter is almost the same after mastectomy or BCS, whether patients received radiation therapy or not [22]. Local recurrences after mastectomy are, however, mostly invasive and are associated with $10-15 \%$ long-term metastases risks and poorer overall survival [12,13,21,24,25]. Using the University of Southern California/Van Nuys Prognostic Index, Kelley et al. analysed data from 496 patients treated with mastectomy, none of whom received any form of adjuvant treatment. The 12-year probability of disease recurrence was $9.6 \%$ for patients scoring 10-12 vs $0 \%$ for those scoring 4-9 $(\mathrm{p}=0.0004)$. The authors concluded that 10 of every 100 patients with USC/VNPI scores of 10-12, will relapse within 12 years and 2-3 will develop metastatic disease [15].

Although the role of WBRT in reducing in situ and invasive local failure rates even in women with low-risk tumours has long been established [8,26,27], clear indications for PMRT have yet to be defined. Since few retrospective studies, often with small cohorts, have investigated the topic, identifying appropriate risk factors seems crucial to justify PMRT in patients with DCIS [13-19,25], and even more, when the number of mastectomies for the treatment of DCIS is increasing in recent years, including an increasing tendency to perform a bilateral mastectomy at the diagnosis of DCIS [28]. 
Margin status plays a major role in local recurrence. Almost one-fifth of UK breast surgeons would consider PMRT in pure DCIS with close/positive margins [23]. Rashtian et al. observed that mastectomized patients with high-grade DCIS and resection margins $<2 \mathrm{~mm}$ presented local recurrence rates of $16 \%$ vs $2 \%$ when the margin was $>2 \mathrm{~mm}$ (p $=$ 0.035) (13). Likewise, Childs et al. observed, at a median follow-up of 7.6 years, $4.5 \%$ local recurrence rates in 44/142 patients with DCIS after mastectomy when margins were positive or close [16]. Despite higher local recurrence rates in other series of mastectomized patients with pure DCIS and close/positive margins, the rates of chest wall recurrences were so low that no firm recommendation could be provided for or against PMRT [14,17-19]. In a review of data from more than 21,000 DCIS patients who underwent mastectomy and were included in the National Cancer Database, Jones et al showed, however, that PMRT in DCIS was significantly more frequent with close/positive (16\%) margins than with negative margins (1.5\%) [29].

Additional unfavourable features supporting the administering of PMRT are high-grade disease, comedonecrosis, and age $<50$ or 60 years $[13,17]$. Bannani et al. analyzed postmastectomy loco-regional recurrence rates in 218 women who underwent mastectomy for DCIS or DCIS with microinvasion. After a mean follow-up of 3.2 years, 8 women (3.67\%) developed local recurrences, and $2 / 8$ had simultaneous distant metastasis. In this series, only age $<40$ years at initial diagnosis was identified as a risk factor for locoregional relapse, as none of the other factors emerged as significant [25]. The present survey confirmed that for $80.6 \%$ of responders, margin status (close $<1 \mathrm{~mm}$ ) played a major role in decision-making for PMRT even though most radiation oncologists also considered other risk factors, mainly, high grade, multi-centricity, young age and tumour size over $5 \mathrm{~cm}$.

Surgical approaches also appear to play a role in local recurrences. Skin-sparing mastectomy (SSM) was associated with more local recurrences than standard mastectomy [30.31]. A retrospective analysis by Carlson et al. including 223 women with DCIS treated by SSM revealed a 5.1\% loco-regional recurrence rate. In SSM, close surgical margins $<1 \mathrm{~mm}$ and high-grade disease emerged as risk factors for local recurrence [30]. Timbrell et al. observed a higher rate of loco-regional recurrence after SSM versus simple mastectomy $(5.9 \%$ vs $0 \%, \mathrm{p}=0.012)$. Again, the presence of close or involved margins was, along with young age, the main risk factor for loco-regional recurrence [31]. In the present survey, skin -sparing or nipple-sparing mastectomy were considered major factors supporting PMRT for $16.9 \%$ of radiation oncologists. 
Another issue is the PMRT schedule in DCIS. Moderately hypofractionated RT schemes are now standard in adjuvant treatment of invasive breast carcinoma [32-36], and in DCIS several studies observed no differences comparing moderate hypofractionation with traditional 5-week schemes [37-42]. Whether a boost was required to the surgical scar or not, of all the proposed RT schedules moderate hypofractionation (2.5-3 Gy per fraction) was most popular among responders.

Increasingly, patients undergoing mastectomy are demanding breast reconstruction. When PMRT is necessary, questions arise regarding the type of adequate reconstruction as well as optimal sequence of surgical and radiotherapy treatments. Steadily more, using temporary tissue expanders (TTE) with later change to permanent implants or autologous reconstruction is preferred when considering PMRT [43]. This circumstance forces to increase the care that should be taken in the radiation planning process and raises, sometimes, discrepancies about the use of hypofractionated radiotherapy schemes. Despite the wide acceptance of hypofractionated schemes in PMRT, in presence of IBR the majority opted for the conventional 2 Gy per fraction.

Finally, immunohistochemical analyses were routinely performed in most institutions, even though the results did not impact on therapeutic choices. In fact present responders expressed no consensus on endocrine therapy: $42.9 \%$ would always recommend it in the presence of positive oestrogen receptors, while $33.8 \%$ would never do so and $26.6 \%$ would consider other factors (young age, comedonecrosis, high grade, etc.). Two studies demonstrated tamoxifen reduced the risk of local recurrence $[44,445]$; a systematic review confirmed that it reduced the risk of DCIS-related events in both the ipsilateral and contralateral breasts but had no effect on mortality rates. The number needed to treat to observe a protective effect of tamoxifen against all breast events was 15 when the medication was maintained for 5 years [46]. Two randomized studies (NSABP B-35 and IBIS-II DCIS) demonstrated that anastrazole may be an alternative in post-menopausal women with hormone-receptor positive DCIS [47,48]. Since endocrine treatment with tamoxifen or aromatase inhibitors is not free of side effects, which may discourage their use, lack of compliance among women with DCIS is a well-established problem. Adherence is reported to drop from $67 \%$ in the first year to $30 \%$ in the fifth year $[49,50]$. Finally, administering adjuvant endocrine therapy to all patients with hormone-receptor positive DCIS is, at least, questionable, as it is associated with a significant adverse impact on quality of life [51]. Indeed, the Danish and the Dutch breast cancer guidelines 
advise not administering endocrine therapy, so oestrogen receptor status is even not assessed [52].

\section{Conclusions}

The results of this survey report current clinical practice on PMRT in patients with DCIS and attempts to identify patients at risk of relapse who are suitable candidates for it.

Although PMRT is not routinely used for most women with DCIS, several identified risk factors for recurrence should be discussed with patients during the shared decisionmaking process: positive or very close margins, high-grade tumours, multicentricity, young age, large tumour size and skin-sparing or nipple-sparing mastectomy.

According to the results of this multi-institutional international survey, radiation oncologists are very interested in taking part in future trials addressing this issue, both in retrospective analysis of accumulated experiences and in the development of prospective trials to study the efficacy of PMRT in selected cases of DCIS.

Acknowledgements. The authors thank all the other ATTM Expert Board members:

Ciabattoni A, Franco P, Kouloulias V, Lancellotta V, Masiello V, Pasinetti N, Pfeffer R, Perrucci E, Pirtoli L, Selek U, Trigo L.

\section{Conflict of interest}

The authors have declared no conflict of interest

\section{Founding}

We received no financial support related to this study 


\section{References}

1. Siegel RL, Miller KD, Jemal A. Cancer statistics, 2018. CA Cancer J Clin. 2018 Jan;68(1):7-30. doi: 10.3322/caac. 21442.

2. Wapnir IL, Dignam JJ, Fisher B, Mamounas EP, Anderson SJ, Julian TB, Land SR, Margolese RG, Swain SM, Costantino JP, Wolmark N. Long-term outcomes of invasive ipsilateral breast tumor recurrences after lumpectomy in NSABP B17 and B-24 randomized clinical trials for DCIS. J Natl Cancer Inst. 2011 Mar 16;103(6):478-88. doi: 10.1093/jnci/djr027.

3. Cuzick J, Sestak I, Pinder SE, Ellis IO, Forsyth S, Bundred NJ, Forbes JF, Bishop H, Fentiman IS, George WD. Effect of tamoxifen and radiotherapy in women with locally excised ductal carcinoma in situ: long-term results from the UK/ANZ DCIS trial. Lancet Oncol. 2011 Jan;12(1):21-9. doi: 10.1016/S14702045(10)70266-7.

4. Donker M, Litière S, Werutsky G, Julien JP, Fentiman IS, Agresti R, Rouanet P, de Lara CT, Bartelink H, Duez N, Rutgers EJ, Bijker N. Breast-conserving treatment with or without radiotherapy in ductal carcinoma In Situ: 15-year recurrence rates and outcome after a recurrence, from the EORTC 10853 randomized phase III trial. J ClinOncol. 2013 Nov 10;31(32):4054-9. doi: 10.1200/JCO.2013.49.5077.

5. Wärnberg F, Garmo H, Emdin S, Hedberg V, Adwall L, Sandelin K, Ringberg A, Karlsson P, Arnesson LG, Anderson H, Jirström K, Holmberg L. Effect of radiotherapy after breast-conserving surgery for ductal carcinoma in situ: 20 years follow-up in the randomized SweDCIS Trial. J ClinOncol. 2014 Nov 10;32(32):3613-8. doi: 10.1200/JCO.2014.56.2595.

6. Early Breast Cancer Trialists' Collaborative Group (EBCTCG), Correa C, McGale P, Taylor C, Wang Y, Clarke M, Davies C, Peto R, Bijker N, Solin L, Darby S. Overview of the randomized trials of radiotherapy in ductal carcinoma in situ of the breast. J Natl Cancer Inst Monogr. 2010;2010(41):162-77. doi: 10.1093/jncimonographs/lgq039.

7. McCormick B, Winter K, Hudis C, Kuerer HM, Rakovitch E, Smith BL, Sneige N, Moughan J, Shah A, Germain I, Hartford AC, Rashtian A, Walker EM, Yuen A, Strom EA, Wilcox JL, Vallow LA, Small W Jr, Pu AT, Kerlin K, White J. RTOG 9804: a prospective randomized trial for good-risk ductal carcinoma in situ 
comparing radiotherapy with observation. J ClinOncol. 2015 Mar 1;33(7):709-15. doi: 10.1200/JCO.2014.57.9029.

8. Solin LJ, Gray R, Hughes LL, Wood WC, Lowen MA, Badve SS, Baehner FL, Ingle JN, Perez EA, Recht A, Sparano JA, Davidson NE. Surgical Excision Without Radiation for Ductal Carcinoma in Situ of the Breast: 12-Year Results From the ECOG-ACRIN E5194 Study. J ClinOncol. 2015 Nov 20;33(33):393844. doi: 10.1200/JCO.2015.60.8588.

9. Rakovitch E, Nofech-Mozes S, Hanna W, Sutradhar R, Gu S, Fong C, Tuck A, Youngson B, Miller N, Done SJ, Chang MC, Sengupta S, Elavathil L, Jani PA, Bonin M, Lalani N, Paszat L. Omitting radiation therapy after lumpectomy for pure DCIS does not reduce the risk of salvage mastectomy. Breast. 2018 Feb;37:181-186. doi: 10.1016/j.breast.2017.07.002.

10. Pesce CE, Liederbach E, Czechura T, Winchester DJ, Yao K. Changing surgical trends in young patients with early stage breast cancer, 2003 to 2010: a report from the National Cancer Data Base. J Am Coll Surg. 2014 Jul;219(1):19-28. doi: 10.1016/j.jamcollsurg.2014.03.043.

11. Rutter CE, Park HS, Killelea BK, Evans SB. Growing Use of Mastectomy for Ductal Carcinoma-In Situ of the Breast Among Young Women in the United States. Ann SurgOncol. 2015 Jul;22(7):2378-86. doi: 10.1245/s10434-014-4334$\mathrm{X}$.

12. Chadha M, Portenoy J, Boolbol SK, Gillego A, Harrison LB. Is there a role for postmastectomy radiation therapy in ductal carcinoma in situ? Int J SurgOncol. 2012;2012:423520. doi: 10.1155/2012/423520.

13. Rashtian A, Iganej S, Amy Liu IL, Natarajan S. Close or positive margins after mastectomy for DCIS: pattern of relapse and potential indications for radiotherapy. Int J RadiatOncolBiol Phys. 2008 Nov 15;72(4):1016-20. doi: 10.1016/j.ijrobp.2008.06.1954

14. Klein J, Kong I, Paszat L, et al. Close or positive resection margins are not associated with an increased risk of chest wall recurrence in women with DCIS treated by mastectomy: a population-based analysis. Springerplus. 2015;4:335. Published 2015 Jul 10. doi:10.1186/s40064-015-1032-5

15. Kelley L, Silverstein M, Guerra L. Analyzing the risk of recurrence after mastectomy for DCIS: a new use for the USC/Van Nuys Prognostic Index. Ann SurgOncol. 2011 Feb;18(2):459-62. doi: 10.1245/s10434-010-1335-2. 
16. Childs SK, Chen YH, Duggan MM, Golshan M, Pochebit S, Punglia RS, Wong JS, Bellon JR. Impact of margin status on local recurrence after mastectomy for ductal carcinoma in situ. Int J RadiatOncolBiol Phys. 2013 Mar 15;85(4):948-52. doi: 10.1016/j.ijrobp.2012.07.2377.

17. Clements K, Dodwell D, Lawrence G, Ball G, Francis A, Pinder S, Sawyer E, Wallis M, Thompson AM; Sloane Project Steering Group. Radiotherapy after mastectomy for screen-detected ductal carcinoma in situ. Eur J SurgOncol. 2015 Oct;41(10):1406-10. doi: 10.1016/j.ejso.2015.07.021.

18. Chan LW, Rabban J, Hwang ES, Bevan A, Alvarado M, Ewing C, Esserman L, Fowble B. Is radiation indicated in patients with ductal carcinoma in situ and close or positive mastectomy margins? Int J RadiatOncolBiol Phys. 2011 May 1;80(1):25-30. doi: 10.1016/j.ijrobp.2010.01.044.

19. Fitzsullivan E, Lari SA, Smith B, et al. Incidence and consequence of close margins in patients with ductal carcinoma-in situ treated with mastectomy: is further therapy warranted?. Ann SurgOncol. 2013;20(13):4103-12.

20. Aristei C, Kaidar-Person O, Arenas M, Coles C, Offersen BV, Bourgier C, Frezza G, Leonardi MC, Valentini V, Poortmans PM. The 2016 Assisi Think Tank Meeting on breast cancer: white paper.Breast Cancer Res Treat. 2016;160(2):211-221

21. Shah C, Vicini FA, Berry S, Julian TB, Wilkinson JB, Shaitelman SF, Khan A, Finkelstein SE, Goldstein N. Ductal Carcinoma In Situ of the Breast: Evaluating the Role of Radiation Therapy in the Management and Attempts to Identify Lowrisk Patients. Am J ClinOncol. 2015 Oct;38(5):526-33. doi: 10.1097/COC.0000000000000102.

22. Giannakeas V, Sopik V, Narod SA. Association of Radiotherapy With Survival in Women Treated for Ductal Carcinoma In Situ With Lumpectomy or Mastectomy. JAMA Netw Open. 2018;1(4):e181100. doi:10.1001/jamanetworkopen.2018.1100

23. Mallon PT, McIntosh SA. Post mastectomy radiotherapy in breast cancer: a survey of current United Kingdom practice. J BUON. 2012 Apr-Jun;17(2):245-8.

24. Vargas C, Kestin L, Go N, Krauss D, Chen P, Goldstein N, Martinez A, Vicini FA. Factors associated with local recurrence and cause-specific survival in patients with ductal carcinoma in situ of the breast treated with breast-conserving therapy or mastectomy. Int J Radiat Oncol Biol Phys. 2005 Dec 1;63(5):1514-21. 
25. Bannani S, Rouquette S, Bendavid-Athias C, Tas P, Levêque J. The locoregional recurrence post-mastectomy for ductal carcinoma in situ: Incidence and risk factors. Breast. 2015 Oct;24(5):608-12. doi: 10.1016/j.breast.2015.06.005.

26. Elshof LE, Schaapveld M, Schmidt MK, Rutgers EJ, van Leeuwen FE, Wesseling J. Subsequent risk of ipsilateral and contralateral invasive breast cancer after treatment for ductal carcinoma in situ: incidence and the effect of radiotherapy in a population-based cohort of 10,090 women. Breast Cancer Res Treat. 2016 Oct;159(3):553-63. doi: 10.1007/s10549-016-3973-y.

27. McCormick B. Randomized Trial Evaluating Radiation following Surgical Excision for “Good Risk” DCIS: 12-Year Report from NRG/ RTOG 98042018 ASTRO Annual Meeting Late-breaking Abstract Selection Int J RadiatOncolBiol Phys Nov;102 (3) (Supplement)

28. Meattini I, Lambertini M, Isacco D, De Caluwé A, Kaidar-Person O, Livi L Lorenzo. Radiation therapy for young women with early breast cancer: Current state of the art. Critical Reviews in Oncology/Hematology 2019;137. 10.1016/j.critrevonc.2019.02.014.

29. Jones CE, Richman J, Jackson BE, Wallace AS, Krontiras H, Urist MM, Bland KI, Parker CC. Treatment patterns for ductal carcinoma in situ with close or positive mastectomy margins. J Surg Res. 2018 Nov;231:36-42. doi:10.1016/j.jss.2018.05.007.

30. Carlson GW, Page A, Johnson E, Nicholson K, Styblo TM, Wood WC. Local recurrence of ductal carcinoma in situ after skin-sparing mastectomy. J Am Coll Surg. 2007 May;204(5):1074-8; discussion 1078-80.

31. Timbrell S, Al-Himdani S, Shaw O, Tan K, Morris J, Bundred N. Comparison of Local Recurrence After Simple and Skin-Sparing Mastectomy Performed in Patients with Ductal Carcinoma In Situ. Ann SurgOncol. 2017 Apr;24(4):10711076. doi: 10.1245/s10434-016-5673-6.

32. Whelan TJ, Pignol JP, Levine MN, Julian JA, MacKenzie R, Parpia S, Shelley W, Grimard L, Bowen J, Lukka H, Perera F, Fyles A, Schneider K, Gulavita S, Freeman C. Long-term results of hypofractionated radiation therapy for breast cancer. N Engl J Med. 2010 Feb 11;362(6):513-20. doi: 10.1056/NEJMoa0906260.

33. START Trialists' Group, Bentzen SM, Agrawal RK, Aird EG, Barrett JM, BarrettLee PJ, Bentzen SM, Bliss JM, Brown J, Dewar JA, Dobbs HJ, Haviland JS, 
Hoskin PJ, Hopwood P, Lawton PA, Magee BJ, Mills J, Morgan DA, Owen JR, Simmons S, Sumo G, Sydenham MA, Venables K, Yarnold JR. The UK Standardisation of Breast Radiotherapy (START) Trial B of radiotherapy hypofractionation for treatment of early breast cancer: a randomised trial. Lancet. 2008 Mar 29;371(9618):1098-107. doi: 10.1016/S0140-6736(08)60348-7.

34. START Trialists' Group, Bentzen SM, Agrawal RK, Aird EG, Barrett JM, BarrettLee PJ, Bliss JM, Brown J, Dewar JA, Dobbs HJ, Haviland JS, Hoskin PJ, Hopwood P, Lawton PA, Magee BJ, Mills J, Morgan DA, O en JR, Simmons S, Sumo G, Sydenham MA, Venables K, Yarnold JR. The UK Standardisation of Breast Radiotherapy (START) Trial A of radiotherapy hypofractionation for treatment of early breast cancer: a randomized trial. Lancet Oncol. 2008 Apr;9(4):331-41. doi: 10.1016/S1470 2045(08)70077-9.

35. Tsang Y, Haviland J, Venables K, Yarnold J, FTM Group. The impact of dose heterogeneity on late normal tissue complication risk after hypofractionated whole breast radiotherapy, Radiother. Oncol. 104 (2012) 143-147.

36. Montero A, Sanz X, Hernanz R, Cabrera D, Arenas M, Bayo E, Moreno F, Algara M. Accelerated hypofractionated breast radiotherapy: FAQs (frequently asked questions) and facts. Breast. 2014 Aug;23(4):299-309. doi:10.1016/j.breast.2014.01.011.

37. Williamson D, Dinniwell R, Fung S, Pintilie M, Done SJ, Fyles AW. Local control with conventional and hypofractionated adjuvant radiotherapy after breastconserving surgery for ductal carcinoma in-situ. RadiotherOncol. 2010 Jun;95(3):317-20. doi: 0.1016/j.radonc.2010.03.021.

38. Wai ES, Lesperance ML, Alexander CS, Truong PT, Culp M, Moccia P, Lindquist JF, Olivotto IA. Effect of radiotherapy boost and hypofractionation on outcomes in ductal carcinoma in situ. Cancer. 2011 Jan 1;117(1):54-62. doi: $10.1002 /$ cncr.25344.

39. Ciervide R, Dhage S, Guth A, Shapiro RL, Axelrod DM, Roses DF, Formenti SC. Five year outcome of 145 patients with ductal carcinoma in situ (DCIS) after accelerated breast radiotherapy. Int J RadiatOncolBiol Phys. 2012 Jun 1;83(2):e159-64. doi: 10.1016/j.ijrobp.2011.11.025.

40. Hathout L, Hijal T, Théberge V, Fortin B, Vulpe H, Hogue JC, Lambert C, Bahig H, Provencher L, Vavassis P, Yassa M. Hypofractionated radiation therapy for 
breast ductal carcinoma in situ. Int J RadiatOncolBiol Phys. 2013 Dec 1;87(5):1058-63. doi: 10.1016/j.ijrobp.2013.08.026.

41. Lalani N, Paszat L, Sutradhar R, Thiruchelvam D, Nofech-Mozes S, Hanna W, Slodkowska E, Done SJ, Miller N, Youngson B, Tuck A, Sengupta S, Elavathil L, Chang MC, Jani PA, Bonin M, Rakovitch E. Long-term outcomes of hypofractionation versus conventional radiation therapy after breast-conserving surgery for ductal carcinoma in situ of the breast. Int J RadiatOncolBiol Phys. 2014 Dec 1;90(5):1017-24. doi: 10.1016/j.ijrobp.2014.07.026.

42. Isfahanian $\mathrm{N}$, Al-Hajri $\mathrm{T}$, Marginean $\mathrm{H}$, Chang $\mathrm{L}$, Caudrelier JM. Hypofractionation Is an Acceptable Alternative to Conventional Fractionation in the Treatment of Postlumpectomy Ductal Carcinoma In Situ With Radiotherapy. Clin Breast Cancer. 2017 Apr;17(2):e77-e85. doi: 10.1016/j.clbc.2016.10.005.

43. Strach MC, Prasanna T, Kirova YM, Alran S, O'Toole S, Beith JM, Poortmans P, McNeil CM, Carroll S. Optimise not compromise: The importance of a multidisciplinary breast cancer patient pathway in the era of oncoplastic and reconstructive surgery. Crit Rev Oncol Hematol. 2019 Feb;134:10-21. doi: 10.1016/j.critrevonc.2018.11.007.

44. Fisher B, Dignam J, Wolmark N, Wickerham DL, Fisher ER, Mamounas E, Smith R, Begovic M, Dimitrov NV, Margolese RG, Kardinal CG, Kavanah MT, Fehrenbacher L, Oishi RH. Tamoxifen in treatment of intraductal breast cancer: National Surgical Adjuvant Breast and Bowel Project B-24 randomised controlled trial. Lancet. 1999 Jun 12;353(9169):1993-2000.

45. Cuzick J, Sestak I, Pinder SE, Ellis IO, Forsyth S, Bundred NJ Forbes JF, Bishop H, Fentiman IS, George WD. Effect of tamoxifen and radiotherapy in women with locally excised ductal carcinoma in situ: long-term results from the UK/ANZ DCIS trial. Lancet Oncol. 2011 Jan;12(1):21-9. doi: 10.1016/S14702045(10)70266-7.

46. Staley H, McCallum I, Bruce J. Postoperative Tamoxifen for ductal carcinoma in situ: Cochrane systematic review and meta-analysis. Breast. 2014 Oct;23(5):54651. doi: 10.1016/j.breast.2014.06.015.

47. Margolese RG, Cecchini RS, Julian TB, Ganz PA, Costantino JP, Vallow LA, Albain KS, Whitworth PW, Cianfrocca ME, Brufsky AM, Gross HM, Soori GS, Hopkins JO, Fehrenbacher L, Sturtz K, Wozniak TF, Seay TE, Mamounas EP, Wolmark N. Anastrozole versus tamoxifen in postmenopausal women with ductal 
carcinoma in situ undergoing lumpectomy plus radiotherapy (NSABP B-35): a randomised, double-blind, phase 3 clinical trial. Lancet. 2016 Feb 27;387(10021):849-56. doi: 10.1016/S0140-6736(15)01168-X.

48. Forbes JF, Sestak I, Howell A, Bonanni B, Bundred N, Levy C, von Minckwitz G, Eiermann W, Neven P, Stierer M, Holcombe C, Coleman RE, Jones L, Ellis I, Cuzick J; IBIS-II investigators. Anastrozole versus tamoxifen for the prevention of locoregional and contralateral breast cancer in postmenopausal women with locally excised ductal carcinoma in situ (IBIS-II DCIS): a double-blind, randomized controlled trial. Lancet. 2016 Feb 27;387(10021):866-73. doi: 10.1016/S0140-6736(15)01129-0.

49. Zhao H, Hei N, Wu Y, Chan W, Lei X, Cameron C, Chang S, Chavez-MacGregor M, Giordano SH. Initiation of and adherence to tamoxifen and aromatase inhibitor therapy among elderly women with ductal carcinoma in situ. Cancer. 2017 May 15;123(6):940-947. doi: 10.1002/cncr.30425.

50. Karavites LC, Kane AK, Zaveri S, Xu Y, Helenowski I, Hansen N, Bethke KP, Rasmussen-Torvik LJ, Khan SA. Tamoxifen Acceptance and Adherence among Patients with Ductal Carcinoma In Situ (DCIS) Treated in a Multidisciplinary Setting. Cancer Prev Res (Phila). 2017 Jul;10(7):389-397. doi: 10.1158/19406207.CAPR-17-0029.

51. Ganz PA, Cecchini RS, Julian TB, Margolese RG, Costantino JP, Vallow LA, Albain KS, Whitworth PW, Cianfrocca ME, Brufsky AM, Gross HM, Soori GS, Hopkins JO, Fehrenbacher L, Sturtz K, Wozniak TF, Seay TE, Mamounas EP, Wolmark N. Patient-reported outcomes with anastrozole versus tamoxifen for postmenopausal patients with ductal carcinoma in situ treated with lumpectomy plus radiotherapy (NSABP B-35): a randomised, double-blind, phase 3 clinical trial. Lancet. 2016 Feb 27;387(10021):857-65. doi: 10.1016/S01406736(15)01169-1.

52. Jensen MB, Laenkholm AV, Offersen BV, Christiansen P, Kroman N, Mouridsen HT, Ejlertsen B. The clinical database and implementation of treatment guidelines by the Danish Breast Cancer Cooperative Group in 2007-2016, Acta Oncologica 2018; 57:1, 13-18, DOI: 10.1080/0284186X.2017.1404638 
Fig. 1: number and origin of the radiation oncologists participating in the survey

60

50

40

30

20

L 


\begin{tabular}{|l|l|l|}
\hline $\begin{array}{l}\text { Q2. What type of institution/hospital/department do you work } \\
\text { in? }\end{array}$ & Responders (number) & Responders (\%) \\
\hline University institution/hospital/department & 109 & $76.76 \%$ \\
\hline $\begin{array}{l}\text { Community institution/hospital/department, not university } \\
\text { affiliated }\end{array}$ & 28 & $19.71 \%$ \\
\hline Other & 5 & $3.5 \%$ \\
\hline $\begin{array}{l}\text { Q3. How many years have you been practising as a radiation } \\
\text { oncologist? }\end{array}$ & Responders (number) & Responders (\%) \\
\hline$<5$ years & 7 & $4.9 \%$ \\
\hline $5-10$ years & 27 & $19 \%$ \\
\hline $11-20$ years & 37 & $26.05 \%$ \\
\hline$>20$ years & 71 & $50 \%$ \\
\hline
\end{tabular}

Table 1: Survey responders' workplaces and experience (Q1, Q2) 
Table 2: Clinical decision-making regarding to PMRT, according to survey responders. (Q4-Q8)

\begin{tabular}{|c|c|c|}
\hline $\begin{array}{l}\text { Q4. How many DCIS patients are treated per year by mastectomy in } \\
\text { your institution during the last } 5 \text { years (please, provide the proper } \\
\text { number of patients from your institution database)? }\end{array}$ & $\begin{array}{l}\text { Responders } \\
\text { (number) }\end{array}$ & Responders (\%) \\
\hline$<50$ patients/year & 104 & $73.23 \%$ \\
\hline 50-100 patients/year & 27 & $19.01 \%$ \\
\hline 101-250 patients/year & 8 & $5.63 \%$ \\
\hline$>250$ patients/year & 3 & $2.11 \%$ \\
\hline $\begin{array}{l}\text { Q5. In DCIS patients treated with mastectomy + immediate breast } \\
\text { reconstruction (IBR), is postmastectomy radiation therapy (PMRT) } \\
\text { indicated in any case in your institution? }\end{array}$ & $\begin{array}{l}\text { Responders } \\
\text { (number) }\end{array}$ & Responders (\%) \\
\hline Yes, in most cases & 0 & $0.00 \%$ \\
\hline Sometimes & 14 & $9.85 \%$ \\
\hline Rarely & 102 & $71.83 \%$ \\
\hline $\begin{array}{l}\text { Never, patients with DCIS treated with mastectomy never received } \\
\text { radiation therapy }\end{array}$ & 26 & $18.30 \%$ \\
\hline $\begin{array}{l}\text { Q6. If yes, how many patients per year underwent PMRT during the } \\
\text { last } 5 \text { years (please, provide the proper number of patients from your } \\
\text { institution database) }\end{array}$ & $\begin{array}{l}\text { Responders } \\
\text { (number) }\end{array}$ & Responders (\%) \\
\hline$<5$ patients/year & 122 & $85.91 \%$ \\
\hline 5-10 patients/year & 15 & $10.05 \%$ \\
\hline$>10$ patients/year & 5 & $3.52 \%$ \\
\hline $\begin{array}{l}\text { Q7. When considering PMRT due to tumour size (DCIS }>5 \mathrm{~cm} \text {.), do you } \\
\text { consider any other risk factors supporting PMRT indication? (multiple } \\
\text { choice) }\end{array}$ & $\begin{array}{l}\text { Responders } \\
\text { (number) }\end{array}$ & Responders (\%) \\
\hline Only size $>5 \mathrm{~cm}$ & 16 & $11.11 \%$ \\
\hline High tumour grade & 54 & $37.50 \%$ \\
\hline Surgical margin $<1 \mathrm{~mm}$ & 116 & $80.56 \%$ \\
\hline Multicentriciity & 41 & $28.47 \%$ \\
\hline Simultaneous presence of extensive Lobular Carcinoma In Situ (LCIS) & 10 & $6.94 \%$ \\
\hline $\begin{array}{l}\text { Other* } \\
\text { *(Other included factors such as young age, high Ki-67, extensive } \\
\text { comedonecrosis, as well as those not considering PMRT) }\end{array}$ & 33 & $22.92 \%$ \\
\hline $\begin{array}{l}\text { Q8. When considering PMRT due to surgical margins ( }<1 \mathrm{~mm} \text {.), do you } \\
\text { consider any other risk factors supporting PMRT indication? (multiple } \\
\text { choice) }\end{array}$ & $\begin{array}{l}\text { Responders } \\
\text { (number) }\end{array}$ & Responders (\%) \\
\hline Only margin $<1 \mathrm{~mm}$ & 55 & $38.73 \%$ \\
\hline
\end{tabular}




\begin{tabular}{|l|l|l|}
\hline High tumour grade & 68 & $47.88 \%$ \\
\hline Tumour size $>5 \mathrm{~cm}$ & 53 & $37.32 \%$ \\
\hline Age $<40$ years & 66 & $46.47 \%$ \\
\hline
\end{tabular}


Table 3: Clinical decision-making regarding to type of mastectomy and breast reconstruction, according to survey responders. (Q9-Q11)

\begin{tabular}{|l|l|l|}
\hline $\begin{array}{l}\text { Q9. If the patient has been treated with IBR, do you change the } \\
\text { indication of PMRT? }\end{array}$ & $\begin{array}{l}\text { Responders } \\
\text { (number) }\end{array}$ & Responders (\%) \\
\hline Always, in that case I would never indicate PMRT & 9 & $6.33 \%$ \\
\hline Never, IBR does not modify PMRT indication & 81 & $57.04 \%$ \\
\hline Sometimes & 52 & $36.62 \%$ \\
\hline $\begin{array}{l}\text { Q10. If the patient has been treated with IBR, would surgical } \\
\text { technique (heterologous vs. autologous reconstruction) change your } \\
\text { PMRT indication? }\end{array}$ & $\begin{array}{l}\text { Responders } \\
\text { (number) }\end{array}$ & Responders (\%) \\
\hline $\begin{array}{l}\text { Always, in cases of IBR using heterologous (prosthesis), I never indicate } \\
\text { PMRT }\end{array}$ & 3 & $2.11 \%$ \\
\hline $\begin{array}{l}\text { Always, in cases of IBR using autologous, I never indicate PMRT } \\
\text { Never, IBR surgical modalities do not modify PMRT indication }\end{array}$ & 4 & 2.81 " \\
\hline Sometimes & 38 & $68.30 \%$ \\
\hline $\begin{array}{l}\text { Q11. If the patient has been treated with skin sparing or nipple } \\
\text { sparing mastectomy, does it modify your PMRT indications? }\end{array}$ & $\begin{array}{l}\text { Responders } \\
\text { (number) }\end{array}$ & Responders (\%) \\
\hline $\begin{array}{l}\text { Always, in cases of skin sparing or nipple sparing mastectomy, PMRT is } \\
\text { more indicated }\end{array}$ & 24 & $16.90 \%$ \\
\hline $\begin{array}{l}\text { Never, skin sparing or nipple sparing mastectomy does not modify } \\
\text { PMRT indication }\end{array}$ & 62 & $39.43 \%$ \\
\hline Sometimes & 56 & $43.66 \%$ \\
\hline
\end{tabular}

Table 4: Clinical decision-making regarding to radiation therapy techniques, according to survey responders. (Q12-Q19)

\begin{tabular}{|l|l|l|}
\hline $\begin{array}{l}\text { Q12In the case of PMRT following mastectomy and IBR, will you } \\
\text { consider the use of a boost? }\end{array}$ & $\begin{array}{l}\text { Responders } \\
\text { (number) }\end{array}$ & Responders (\%) \\
\hline Yes, all patients are planned for scar boost (and other high risk regions) & 3 & $2.11 \%$ \\
\hline Yes, only if tumour size $>5 \mathrm{~cm}$ & 0 & $0 \%$ \\
\hline
\end{tabular}




\begin{tabular}{|c|c|c|}
\hline Yes, only in closed and/or in positive margins & 71 & $50 \%$ \\
\hline No, never & 68 & $47.88 \%$ \\
\hline $\begin{array}{l}\text { Q13In case of using PMRT after IBR, is intensity modulated radiation } \\
\text { therapy performed (IMRT, including VMAT, Tomotherapy, etc)? (not } \\
\text { consider "forward IMRT" or "multisegments" technique)? }\end{array}$ & $\begin{array}{l}\text { Responders } \\
\text { (number) }\end{array}$ & Responders (\%) \\
\hline Always & 22 & $15.49 \%$ \\
\hline Sometimes & 27 & $19.01 \%$ \\
\hline $\begin{array}{l}\text { Rarely - only for complex volumes or that 3D plan does not meet dose } \\
\text { constrains }\end{array}$ & 67 & $47.18 \%$ \\
\hline $\begin{array}{l}\text { IMRT is never indicated and/or is not available for these indications in } \\
\text { my institution }\end{array}$ & 26 & $18.03 \%$ \\
\hline $\begin{array}{l}\text { Q14When considering PMRT without IBR, will you use a bolus on } \\
\text { chest wall? }\end{array}$ & $\begin{array}{l}\text { Responders } \\
\text { (number) }\end{array}$ & Responders (\%) \\
\hline Never & 51 & $35.91 \%$ \\
\hline Yes, daily through all the treatment & 9 & $6.33 \%$ \\
\hline Yes, on alternate days & 7 & $4.92 \%$ \\
\hline Yes, only the first half of treatment (eg. first $12-13$ out of 25 fractions) & 9 & $6.33 \%$ \\
\hline Yes, depending on the treatment plan & 66 & $46.47 \%$ \\
\hline $\begin{array}{l}\text { Q15What is the dose regimen used for exclusive chest wall } \\
\text { irradiation? }\end{array}$ & $\begin{array}{l}\text { Responders } \\
\text { (number) }\end{array}$ & Responders (\%) \\
\hline $\begin{array}{l}\text { Conventional fractionation (1.8-2.1Gy per fraction, over 25-28 } \\
\text { fractions) }\end{array}$ & 58 & $40.84 \%$ \\
\hline $\begin{array}{l}\text { Hypofractionated schedule (2.5-3.0 Gy per fraction / over 13-16 } \\
\text { fractions) }\end{array}$ & 63 & $44.36 \%$ \\
\hline $\begin{array}{l}\text { Accelerated, b.i.d. fractionation at } 1.5 \text { Gy per fraction to a dose of }>45 \\
\text { Gy }\end{array}$ & 0 & $0 \%$ \\
\hline Two of the above fractionations schemes, varies between cases & 16 & $11.42 \%$ \\
\hline All of the above fractionations schemes, varies between cases & 2 & $1.40 \%$ \\
\hline $\begin{array}{l}\text { Other (please specify)* } \\
\text { Other*: including never considered treatment }\end{array}$ & 3 & $2.11 \%$ \\
\hline $\begin{array}{l}\text { Q16What is the dose regimen used for exclusive chest wall irradiation } \\
\text { in case of IBR? }\end{array}$ & $\begin{array}{l}\text { Responders } \\
\text { (number) }\end{array}$ & Responders (\%) \\
\hline $\begin{array}{l}\text { Conventional fractionation (1.8-2.1Gy per fraction, over 25-28 } \\
\text { fractions) }\end{array}$ & 81 & $57.04 \%$ \\
\hline $\begin{array}{l}\text { Hypofractionated schedule (2.5-3.0 Gy per fraction / over 13-16 } \\
\text { fractions) }\end{array}$ & 44 & $30.98 \%$ \\
\hline $\begin{array}{l}\text { Accelerated, b.i.d. fractionation at } 1.5 \text { Gy per fraction to a dose of > } 45 \\
\text { Gy }\end{array}$ & 0 & $0 \%$ \\
\hline
\end{tabular}




\begin{tabular}{|c|c|c|}
\hline Two of the above fractionations schemes, varies between cases & 14 & $9.85 \%$ \\
\hline All of the above fractionations schemes, varies between cases & 0 & $0 \%$ \\
\hline $\begin{array}{l}\text { Other (please specify)* } \\
\text { Other*: including never considered treatment }\end{array}$ & 3 & $2.11 \%$ \\
\hline $\begin{array}{l}\text { Q17If a boost is added to chest wall irradiation, what is your favourite } \\
\text { schedule? }\end{array}$ & $\begin{array}{l}\text { Responders } \\
\text { (number) }\end{array}$ & Responders (\%) \\
\hline Conventional fractionation (1.8-2.1Gy per fraction) & 70 & $42.29 \%$ \\
\hline Hypofractionated schedule (2.5-3.0 Gy per fraction) & 58 & $40.84 \%$ \\
\hline Accelerated, b.i.d. fractionation at 1.5 Gy per fraction & 0 & $0 \%$ \\
\hline $\begin{array}{l}\text { Other (please specify)* } \\
\text { Other*: including simultaneous integrated boost or never considered } \\
\text { boost }\end{array}$ & 14 & $9.85 \%$ \\
\hline $\begin{array}{l}\text { Q18If a boost is added to chest wall irradiation after IBR, what is your } \\
\text { favourite schedule? }\end{array}$ & $\begin{array}{l}\text { Responders } \\
\text { (number) }\end{array}$ & Responders (\%) \\
\hline Conventional fractionation (1.8-2.1Gy per fraction) & 84 & $59.15 \%$ \\
\hline Hypofractionated schedule (2.5-3.0 Gy per fraction) & 44 & $30.98 \%$ \\
\hline Accelerated, b.i.d. fractionation at 1.5 Gy per fraction & 0 & $0 \%$ \\
\hline $\begin{array}{l}\text { Other (please specify)* } \\
\text { Other*: including simultaneous integrated boost or never considered } \\
\text { boost }\end{array}$ & 14 & $40.84 \%$ \\
\hline
\end{tabular}


Table 5: Clinical decision-making regarding to hormonotherapy use in DCIS, according to survey responders. (Q19-Q21)

\begin{tabular}{|c|c|c|}
\hline $\begin{array}{l}\text { Q19. In DCIS treated by mastectomy, are there any } \\
\text { immunohistochemistry (IHC) analysis routinely performed at your } \\
\text { institution? If yes, what kind of IHC analysis? (multiple choice) }\end{array}$ & $\begin{array}{l}\text { Responders } \\
\text { (number) }\end{array}$ & Responders (\%) \\
\hline Oestrogen receptors (ER) & 112 & $78.87 \%$ \\
\hline Progesterone receptors (PR) & 101 & $71.12 \%$ \\
\hline HER2 & 50 & 35.21 \\
\hline Ki-67 & 78 & $54.92 \%$ \\
\hline Never performed IHC analysis for DCIS & 30 & $21.12 \%$ \\
\hline $\begin{array}{l}\text { Q20. In ER+ DCIS treated by mastectomy, do you consider hormonal } \\
\text { treatment? (multiple choice) }\end{array}$ & $\begin{array}{l}\text { Responders } \\
\text { (number) }\end{array}$ & Responders (\%) \\
\hline Yes, always & 61 & $42.95 \%$ \\
\hline No, never & 48 & $33.80 \%$ \\
\hline $\begin{array}{l}\text { Sometimes (please, specify)* } \\
\text { Sometimes*: considered at young age, high grade, tumour size, positive } \\
\text { margins, patient's decision, }\end{array}$ & 35 & $26.64 \%$ \\
\hline $\begin{array}{l}\text { Q21. In case you consider hormonal treatment for DCIS after } \\
\text { mastectomy, which do you choose? (multiple choice) }\end{array}$ & $\begin{array}{l}\text { Responders } \\
\text { (number) }\end{array}$ & Responders (\%) \\
\hline Tamoxifen & 67 & $47.18 \%$ \\
\hline Aromatase inhibitors & 11 & $7.74 \%$ \\
\hline Depending upon patient hormonal status & 71 & $50 \%$ \\
\hline
\end{tabular}


Table 6: Interest in future trials participation, according to survey responders. (Q23, Q24)

\begin{tabular}{|l|l|l|}
\hline $\begin{array}{l}\text { Q22. In case you treat DCIS by PMRT, would you agree to participate in } \\
\text { a retrospective study reviewing these patients? }\end{array}$ & $\begin{array}{l}\text { Responders } \\
\text { (number) }\end{array}$ & Responders (\%) \\
\hline Yes & 123 & $86.61 \%$ \\
\hline No & 19 & $13.38 \%$ \\
\hline $\begin{array}{l}\text { Q23. If PMRT is considered for selected DCIS patients, would you } \\
\text { accept to participate in a future randomized study? }\end{array}$ & $\begin{array}{l}\text { Responders } \\
\text { (number) }\end{array}$ & Responders (\%) \\
\hline Yes & 124 & $87.32 \%$ \\
\hline No & 18 & $12.67 \%$ \\
\hline
\end{tabular}

